The University of Southern Mississippi

The Aquila Digital Community

Faculty Publications

$5-1991$

\title{
Osmophores, Floral Features, and Systematics of Stanhopea (Orchidaceae)
}

\author{
Kenneth J. Curry \\ University of Southern Mississippi, Kenneth.Curry@usm.edu \\ Lorraine M. McDowell \\ University of Florida \\ Walter S. Judd \\ University of Florida, lyonia@ufl.edu \\ William Louis Stern \\ University of Florida
}

Follow this and additional works at: https://aquila.usm.edu/fac_pubs

Part of the Botany Commons

\section{Recommended Citation}

Curry, K. J., McDowell, L. M., Judd, W. S., Stern, W. L. (1991). Osmophores, Floral Features, and Systematics of Stanhopea (Orchidaceae). American Journal of Botany, 78(5), 610-623.

Available at: https://aquila.usm.edu/fac_pubs/9

This Article is brought to you for free and open access by The Aquila Digital Community. It has been accepted for inclusion in Faculty Publications by an authorized administrator of The Aquila Digital Community. For more information, please contact Joshua.Cromwell@usm.edu. 
Osmophores, Floral Features, and Systematics of Stanhopea (Orchidaceae)

Author(s): Kenneth J. Curry, Lorraine M. McDowell, Walter S. Judd, William Louis Stern

Reviewed work(s):

Source: American Journal of Botany, Vol. 78, No. 5 (May, 1991), pp. 610-623

Published by: Botanical Society of America

Stable URL: http://www.jstor.org/stable/2445082

Accessed: 14/11/2011 09:49

Your use of the JSTOR archive indicates your acceptance of the Terms \& Conditions of Use, available at http://www.jstor.org/page/info/about/policies/terms.jsp

JSTOR is a not-for-profit service that helps scholars, researchers, and students discover, use, and build upon a wide range of content in a trusted digital archive. We use information technology and tools to increase productivity and facilitate new forms of scholarship. For more information about JSTOR, please contact support@ jstor.org. 


\title{
OSMOPHORES, FLORAL FEATURES, AND SYSTEMATICS OF STANHOPEA (ORCHIDACEAE) ${ }^{1}$
}

\author{
KenNeth J. Curry, ${ }^{2}$ Lorraine M. MCDowell, ${ }^{3}$ \\ WALter S. JUdD, ${ }^{3}$ AND WILliam LOUIS STERN ${ }^{3,4}$ \\ ${ }^{2}$ Department of Biological Sciences, University of Southern Mississippi, \\ Hattiesburg, Mississippi 39406-5018; and \\ ${ }^{3}$ Department of Botany, University of Florida, Gainesville, Florida 32611-2009
}

\begin{abstract}
The floral fragrance glands (osmophores) of 18 species of Stanhopea and Sievekingia were examined through a series of developmental studies at light and electron microscope levels including late bud stages through postanthesis. Various characters were identified to be of potential systematic value and were recorded for each species. These characters included: texture of the osmophore surface, number of distinct cell layers comprising the osmophore, nature of lipid inclusions in osmophore cells, and presence or absence of plastoglobuli in osmophore amyloplasts. These characters were combined with traditional features of floral lip morphology for cladistic analysis. Sievekingia was the postulated outgroup. Stanhopea ecornuta showed the largest number of plesiomorphic characters. Stanhopea pulla, S. annulata, and S. candida were only slightly more derived. Stanhopea anfracta, $S$. gibbosa, S. martiana, S. oculata, S. radiosa, S. ruckeri, S. saccata, $S$. shuttleworthii, $S$. tigrina, $S$. vasquezii, and $S$. wardii form a monophyletic group that can be recognized by a labellum with an articulated epichile and a bicornuate mesochile (or hypochile). Stanhopea tricornis may be a hybrid between a species of Sievekingia and Stanhopea.
\end{abstract}

Stanhopea Frost ex Hooker is the type genus of subtribe Stanhopeinae which are all Neotropical epiphytes pollinated exclusively by male euglossine bees. Stanhopea, with about 50 species, is among the largest genera in the subtribe and is characterized by ribbed pseudobulbs, each bearing a single, plicate leaf. The inflorescence is directed downward from the base of the pseudobulb. There are two to 15 simultaneously opening flowers that last 1 or 2 days and are intensely aromatic. The aroma is a combination of terpenes and aromatics (Williams and Whitten, 1983) produced by secretory tissue called the osmophore (Vogel, 1963).

Pollination of plants in this subtribe is unusual in that there is no food reward for the pollinator. Male euglossine bees are attracted to plants by the fragrance produced in the osmophore. Apparently, visual cues are secondary. Bees collect the fragrance which they use presumably as a precursor for a sex pheromone (Dressler, 1982).

\footnotetext{
${ }^{1}$ Received for publication 13 July 1990; revision accepted 3 January 1991.

The authors thank Henry C. Aldrich for use of the Electron Microscope Core Laboratory, University of Florida, and Vicki A. Funk, Smithsonian Institution, for her review which helped us avoid certain embarrassing discrepancies. This study was supported in part by NSF grants DEB 8219120 and BSR-8607212 to WLS.

${ }^{4}$ Author for correspondence.
}

The genus has not been monographed, but Dodson and Frymire (1961; hereinafter referred to without year) suggested an evolutionary scheme (Fig. 1) that included many of the species, and the genus Sievekingia Reichb. f. was suggested as a possible ancestor from which Stanhopea was derived. Dodson (1963, $1975 \mathrm{a}, \mathrm{b})$ has since published additional information concerning individual species of Stanhopea. Dressler (1981) reproduced the original evolutionary scheme (Dodson and Frymire) with little basic change to incorporate new data on plant-pollinator relationships. In a recent personal communication, Dodson indicated the placement in his original scheme of some newly described species.

Flowers of Sievekingia are less specialized than even the least specialized flower of Stanhopea. A labellum may be distinguished from the other two petals by its morphology and the presence of a callus, but it is not sufficiently differentiated to define a hypochile, mesochile, or epichile, as is generally true in Stanhopea. The proximal portion of the labellum behind the callus forms a shallow pouch reminiscent of the pouch in the hypochile of Stanhopea. The floor of this shallow pouch in the labellum contains the osmophore of Sievekingia (Fig. -2).

Classification of Stanhopea is based almost exclusively on characteristics of the labellum. In some species the labellum has become so 


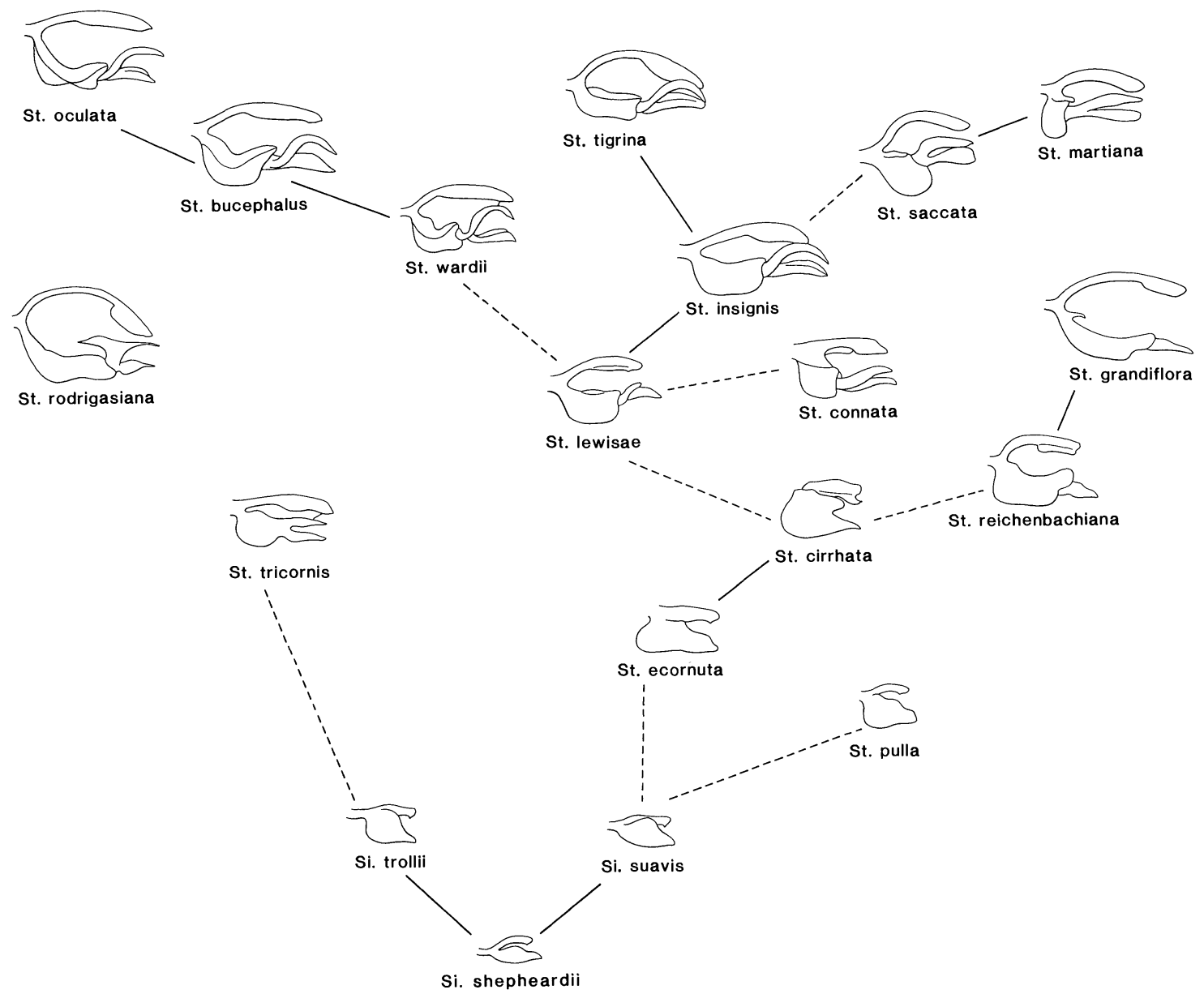

Fig. 1. Representation of Dodson and Frymire's (1961) diagram of labella and columns of Stanhopea and Sievekingia suggesting relationships among the species.

specialized that it may be divided for convenience of reference and discussion into three parts: the proximal hypochile that includes the osmophore, the central mesochile (which may be indistinguishable in some species of Stanhopea), and the distal epichile. The more specialized labella have a mesochile bearing a pair of forward-projecting horns. The epichile is articulated to the mesochile when that structure is present. Petals of Stanhopea flowers (excluding the labellum) are strongly reflexed in all but one species. The column arches parallel along the labellum, and its terminal anther lies in close proximity to the epichile.

Dodson and Frymire suggested that floral characters intimately associated with pollination would be under strong selective pressure, whereas characters less important to pollination would be more variable within a species. They cited high variability in color as an example of a character not intimately associated with pollination. The labellum has become a central focus for Stanhopea taxonomy because its variability and structural complexity allow the identification of numerous fairly constant characters that may be used in species delimitation.

We consider the evolutionary scheme (Fig. 1) proposed by Dodson and Frymire, including the possible ancestral relationship with Sievekingia, to be a useful working hypothesis. Although they did not address the issue, their evolutionary scheme, if accepted, would lead to the consideration of Sievekingia as likely paraphyletic, with Stanhopea being the sister group of a species (or clade) within Sievekingia. The question of the monophyly or paraphyly of Sievekingia is not addressed in our study, and would require the inclusion of additional species of this genus, as well as related genera, in the cladistic analyses. We have examined, through developmental studies, the osmo- 


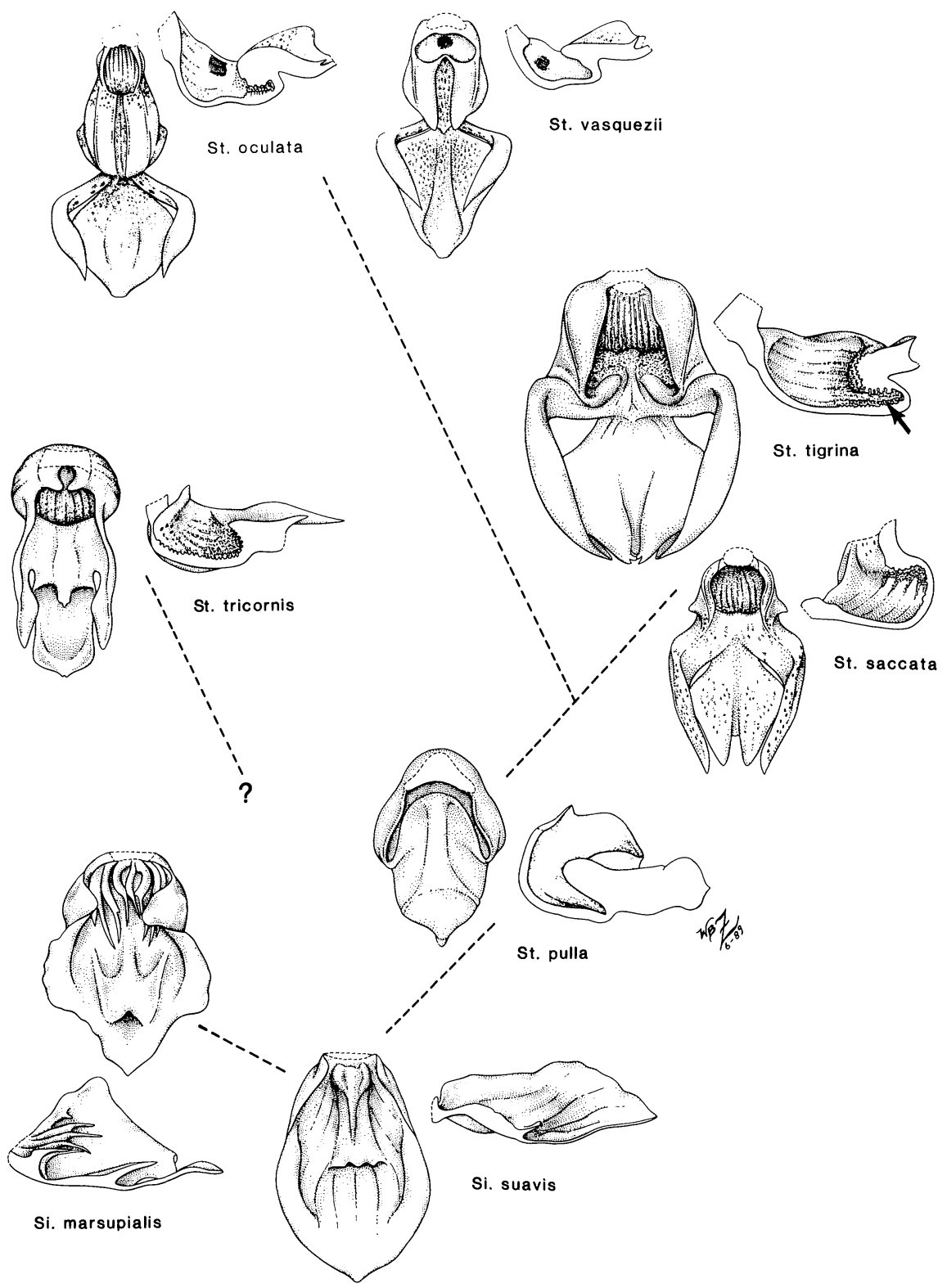

Fig. 2. Representative labella in top and sagittal views organized to depict our approximation of the evolutionary scheme proposed by Dodson and Frymire (1961). Sievekingia suavis is postulated as close to the ancestor of Stanhopea. Stanhopea pulla typifies primitive members of the genus. Stanhopea saccata and $S$. tigrina represent the "insignis" complex, and Stanhopea oculata and S. vasquezii represent the "oculata" complex. Stanhopea tricornis is thought to be a hybrid between Stanhopea and Sievekingia. Top and sagittal views of labella for each species are drawn to scale; however, labella of the different species are not reproduced proportionately. Si = Sievekingia $; \mathrm{St}=$ Stanhopea .

phores of many species of Stanhopea and two species of Sievekingia. Herein we describe characteristics of osmophores of these species and apply a cladistic analysis to the combined osmophore and other floral characteristics to clarify further phylogenetic relationships within Stanhopea, and to test Dodson and Frymire's original scheme.

\section{MATERIALS AND METHODS}

Plants of Stanhopea and Sievekingia used in this study are maintained in the greenhouses of the Department of Botany, University of Florida. The species represented by these plants were the only ones available to us and for this reason we were unable to study all those used 
TABLE 1. Character states of taxa used in cladistic analysis of Stanhopea and Sievekingia ${ }^{\mathrm{a}}$

\begin{tabular}{|c|c|c|c|c|c|c|c|c|c|c|c|c|c|}
\hline Species & $1^{b}$ & 2 & 3 & 4 & 5 & 6 & 7 & 8 & 9 & 10 & 11 & 12 & 13 \\
\hline 1. S. annulata & 1 & 0 & 0 & 0 & 1 & 0 & 1 & 1 & 1 & 0 & 0 & 0 & 0 \\
\hline 2. S. ecornuta & 0 & 0 & 0 & 0 & 1 & 0 & 1 & 1 & 1 & 0 & 0 & 0 & 0 \\
\hline 3. S. pulla & 0 & 0 & 0 & 0 & 1 & 1 & 1 & 1 & 1 & 0 & 0 & 0 & 0 \\
\hline 4. S. candida & 1 & 0 & 0 & 0 & 1 & 1 & 1 & 1 & 1 & 0 & 0 & 0 & 0 \\
\hline 5. S. tricornis & 1 & 0 & 1 & 0 & 0 & 1 & 1 & 0 & 1 & 0 & 1 & 1 & 0 \\
\hline 6. S. martiana & 1 & 1 & 1 & 0 & 0 & 0 & 1 & 1 & 1 & 0 & 1 & 1 & 1 \\
\hline 7. S. tigrina & 1 & 0 & 0 & 0 & 0 & 0 & 1 & 1 & 1 & 1 & 1 & 1 & 1 \\
\hline 8. S. radiosa & 1 & 1 & 1 & 1 & 0 & 0 & 1 & 1 & 1 & 0 & 1 & 1 & 1 \\
\hline 8. S. saccata & 1 & 1 & 1 & 1 & 0 & 0 & 1 & 1 & 1 & 0 & 1 & 1 & 1 \\
\hline 9. S. gibbosa & 1 & 0 & 0 & 0 & 1 & 1 & 0 & 1 & 1 & 1 & 1 & 1 & 0 \\
\hline 10. S. vasquezii & 0 & 0 & 1 & 0 & 0 & 0 & 0 & 1 & 1 & 1 & 1 & 1 & 0 \\
\hline 11. S. anfracta & 1 & 0 & 0 & 0 & 0 & 0 & 0 & 1 & 1 & 1 & 1 & 1 & 0 \\
\hline 11. S. oculata & 1 & 0 & 0 & 0 & 0 & 0 & 0 & 1 & 1 & 1 & 1 & 1 & 0 \\
\hline 11. S. ruckeri & 1 & 0 & 0 & 0 & 0 & 0 & 0 & 1 & 1 & 1 & 1 & 1 & 0 \\
\hline 11. S. shuttle. & 1 & 0 & 0 & 0 & 0 & 0 & 0 & 1 & 1 & 1 & 1 & 1 & 0 \\
\hline 11. S. wardii & 1 & 0 & 0 & 0 & 0 & 0 & 0 & 1 & 1 & 1 & 1 & 1 & 0 \\
\hline 12. Sieve. mars. & 0 & 0 & 1 & 0 & 0 & 0 & 0 & 0 & 0 & $\mathrm{n} / \mathrm{a}$ & 0 & 0 & 0 \\
\hline 12. Sieve suavis & 0 & 0 & 0 & 0 & 0 & 0 & 0 & 0 & 0 & $\mathrm{n} / \mathrm{a}$ & 0 & 0 & 0 \\
\hline
\end{tabular}

a Species 8 and 11 are members of the "insignis" and "oculata" groups, respectively. They are treated as units for cladistic purposes because they are identical for the character set we used. S. shuttle. $=$ S. shuttleworthii. Sieve. mars. = Sievekingia marsupialis. See text for explanation of plesiomorphic (scored 0) and apomorphic (scored 1) conditions.

${ }^{b}$ Numbers heading columns pertain to similarly numbered characters polarized in Table 2 .

by Dodson and Frymire in their scheme (Fig. 1). However, we studied other species not considered by them. In most cases, several plants of each species were examined. Abbreviations of names for authors of binomials follow those recommended by Meikle (1980).

Microscopy-Tissues for study were sampled, where possible, at several developmental stages of the inflorescence beginning with a bud stage the day before the flowers open and proceeding through postanthesis. Flowers reached postanthesis in 1 to 3 days depending on species.

All osmophore tissue was fixed for $2 \mathrm{hr}$ in $2 \%(\mathrm{w} / \mathrm{v})$ formaldehyde (freshly made from paraformaldehyde), $2.5 \%$ (v/v) glutaraldehyde, and $2 \mathrm{mM} \mathrm{CaCl}{ }_{2}$ in $0.1 \mathrm{M}$ cacodylate buffer made to pH 7.2. Material was then buffer-rinsed ( $0.1 \mathrm{M}$ cacodylate, $\mathrm{pH} 7.2)$, postfixed for $45 \mathrm{~min}$ in $1 \%(\mathrm{w} / \mathrm{v})$ osmium tetroxide in $0.1 \mathrm{M}$ cacodylate buffer ( $\mathrm{pH} 7.2)$, buffer-rinsed (0.1 M cacodylate, $\mathrm{pH} 7.2)$, and dehydrated through an ethanol series $(50 \%, 70 \%, 85 \%, 95 \%$, $100 \%$ ) followed by $100 \%$ acetone.

Tissues for light microscopy (LM) and transmission electron microscopy (TEM) were embedded in epoxy resin ERL 4206 (Spurr, 1969). Material for light microscopy was thick-sectioned (ca $1 \mu \mathrm{m})$ and stained with $0.1 \%(\mathrm{w} / \mathrm{v})$ toluidine blue 0 in $1 \%(\mathrm{w} / \mathrm{v})$ sodium borate. Material for TEM was thin-sectioned (ca 90$100 \mathrm{~nm}$ ), stained $12-30 \mathrm{~min}$ in $1 \%(\mathrm{w} / \mathrm{v})$ aqueous uranyl acetate, and poststained 7-10 min in Sato's or Reynolds' lead citrate (Hayat, 1981). Dehydrated material for scanning electron microscopy (SEM) was critical-point dried and gold-coated.

Cladistics-A preliminary analysis of the cladistic relationships of selected species of Stanhopea and Sievekingia was conducted using the branch-and-bound algorithm (Hendy and Penny, 1982) as employed in the PAUP (Phylogenetic Analysis Using Parsimony, Version 2.4) computer program developed by Swofford (1985).

Twelve taxa were used in the analyses (Table 1), based on a survey of morphological and ultrastructural variation in 18 species of Stanhopea and Sievekingia. Species showing identical character states for the subset of characters we used were grouped into operational taxa. Thus, Stanhopea radiosa Lemaire and $S$. saccata Bateman, part of Dodson and Frymire's "insignis" group, and Stanhopea anfracta Rolfe, S. oculata (C. Lodd.) Lindley, S. ruckeri Lindley, $S$. shuttleworthii Reichb. f., and $S$. wardii C. Lodd. ex Lindley, included in Dodson and Frymire's "oculata" group, were combined into two respective groups.

Thirteen characters were delimited (Table 1) and assigned plesiomorphic (ancestral; scored as 0 ) and apomorphic (derived; scored as 1) states. Plesiomorphic and apomorphic features used in the computer analysis are listed in Table 2 , and their assigned numbers correspond with those heading the columns in Table 1. 
TABLE 2. Characters used in cladistic analysis of Stanhopea and Sievekingia

\begin{tabular}{l}
\hline \hline Plesiomorphic (ancestral) \\
\hline 1. Osmophore surface \\
smooth, individual cells \\
bullate \\
2. Osmophore surface \\
lacking unicellular tri- \\
chomes \\
3. Epidermal cells of os- \\
mophore anatomically \\
similar to subjacent \\
cells; tissue homoge- \\
neous \\
4. Cytoplasmic lipid in- \\
clusions of one pat- \\
tern, either uniformly \\
electron dense or mac- \\
ulate
\end{tabular}

5. Cytoplasmic lipid inclusions spherical only (either all electron dense or all with a dark peripheral halo surrounding a less dense center)

6. Plastoglobuli present

7. Inflorescences with 4 or more flowers

8. Petals erect

9. Distinct hypochile lacking

10. Hypochile globose

11. Labellum ecornuate

12. Articulated epichile absent

13. Apex of labellum uniapiculate

${ }^{\text {a }}$ Maculate: spots of electron-dense matter in a less electron-dense matrix.

Characters were polarized by outgroup analysis (Stevens, 1980, 1981; Wheeler, 1981; Wiley, 1981; Maddison, Donoghue, and Maddison, 1984) using Sievekingia suavis Reichb. f. and $S$. marsupialis Dodson. Two characters (numbers 3 and 10 in Table 1) are either variable or not applicable in these species and are therefore unpolarized in the cladistic analyses. Autapomorphic and uniform characters were not included in the analysis because they do not elucidate phylogenetic relationships. However, character 4 (Table 1) was included because this feature is a synapomorphy for $S$. saccata and $S$. radiosa (the two species comprising the "insignis" group). The characters used to analyze cladistic relationships of Stanhopea and Sievekingia are listed in Table 2 followed by explanatory notes in numerical sequence relating to our interpretations of features.

1. See related discussions in Curry, Stern, and McDowell (1988). We view the acquisition of papillae and rugae as a single phenomenon involving clusters of cells and have made no distinction between papillae and rugae and the relative degree of surface convolution.

2. These trichomes are not considered homologous with the large, multicellular trichomes that may be found on the osmophore surface of Sievekingia marsupialis (a probable autapomorphy).

3. See related discussion in Curry, Stern, and McDowell (1988). Because Sievekingia suavis has homogeneous osmophore layers while those in $S$. marsupialis are bilayered, this feature was not polarized in the computer analyses. The polarity assessment given in Table 2 is based on the most parsimonious distribution of character states suggested by the discovered cladograms.

7. Delimitation of the states of this quantitative character is somewhat arbitrary. See Almeida and Bisby (1984) for a discussion of problems in delimiting states in continuously varying measurement data.

10. Since Sievekingia lacks a distinct hypochile the ancestral state was scored as "missing" and the character was considered unpolarized in the cladistic analyses. The polarity presented here is based on the most parsimonious distribution of character states suggested by the discovered cladograms.

13. The single apiculation of the distal margin of the labellum of Sievekingia is comparable to the single apiculation on the distal margin of the epichile of some species of Stanhopea, and these structures are considered to be homologous. The number of apiculations is, therefore, used in the cladistic analyses without regard to the presence or absence of a distinct epichile.

\section{RESULTS}

Developmental studies of osmophores of Stanhopea and Sievekingia listed in Table 1 were pursued wherever possible to establish the sequence of cellular events in this secretory tissue. Each study consisted of a daily sample of tissue from a single flower from a late bud stage through postanthesis. The plants usually bloom annually and produce only a small number of flowers, so multiple plants of a species were used to establish a complete developmental sequence. Stages of development were corroborated with additional floral samples where possible, but, in some cases, a complete study was not possible. Data reported in Table 1 are, to every extent possible, representative of osmophore tissue in a flower during anthesis. 
Tissue in each study was examined by LM and by both SEM and TEM.

Selected morphological characters used by Dodson and Frymire to establish their suggested phylogenetic relationships within the genus Stanhopea, and between Stanhopea and Sievekingia, were examined in our specimens and are reported in Table 1 . Labellum morphology is shown in Fig. 2 and is organized to approximate the evolutionary scheme (Fig. 1) of Dodson and Frymire. Data for numbers of flowers per inflorescence are from our observations and from previously published accounts and descriptions (e.g., Dodson, 1963, 1975a, b; Dodson and Frymire).

Osmophore characters-The osmophore of Stanhopea is located in a pouch at the proximal end of the labellum as illustrated in Stern, Curry, and Pridgeon (1987), Curry, Stern, and McDowell (1988), and as shown at the arrow in Fig. 2. The osmophore of Sievekingia is also located at the proximal end of the labellum, but there is no sharply defined pouch. The osmophore surface was examined in each specimen using SEM. Sievekingia suavis and several species of Stanhopea have flat to bullate osmophore surfaces (Figs. 3, 4). Sievekingia marsupialis has a flat surface with occasional multicellular trichomes. Some species of Stanhopea have osmophore surfaces with multicellular papillae (Fig. 5). The remaining species have an osmophore surface convoluted by rugae and papillae (Fig. 6). Some epidermal cells on the papillae of $S$. saccata (Fig. 7) and $S$. radiosa form distinct, unicellular trichomes. Comparable, but smaller, unicellular trichomes are present on the rugae of $S$. martiana Bateman ex Lindley (Fig. 8).

All osmophores of Stanhopea and Sieveking$i a$ were identified as secretory tissue by the presence of cells with dense cytoplasm (Schnepf, 1969; Fahn, 1979) and numerous starch grains. Secretory tissue grades imperceptibly into ground parenchyma. Examination of the anatomy of osmophore tissue in section at the light microscope level indicated that some osmophores have epidermal cells that are morphologically different from the subjacent cells (Figs. $9,10)$. In other species the osmophore comprised homogeneous layers of cells (Figs. 11, 12).

We have previously examined the ultrastructure of osmophore cells in Stanhopea in some detail (Stern, Curry, and Pridgeon, 1987; Curry, Stern, and McDowell, 1988) and have continued our investigations for this study. There is considerable uniformity of ultrastructure in osmophore cells of both Stanhopea and
Sievekingia species. Cytoplasmic lipid inclusions and plastoglobuli in amyloplasts are two features presumably associated with fragrance production (Curry, 1987; Stern, Curry, and Pridgeon, 1987; Curry, Stern, and McDowell, 1988) that showed sufficient variation for inclusion here as potentially useful characters. Plastoglobuli are present in the amyloplasts of both species of Sievekingia and most, but not all, species of Stanhopea (Figs. 13, 15, 16). Lipid inclusions were observed in unstained sections to verify that they were osmiophilic and, therefore, probably lipid, rather than some other cell inclusion that accepted the uranyl acetate or lead citrate poststains. Three different variations of lipid inclusions were observed. Some of the inclusions tended to be spherical to somewhat irregular and uniformly electron dense (Figs. 13, 16). Stanhopea saccata (Fig. 15) and $S$. radiosa have, in addition to the aforementioned lipid type, another lipid type characterized by a dark ring surrounding a less electron-dense center. Both of these lipid types are present in each osmophore cell of the above-mentioned species. A third variation of lipid inclusion consists of structures that range from spherical to highly irregular. These occur independently of the two previously described types, and are characterized by small patches of electron-dense material in a less electrondense structure (Fig. 14). We refer to this condition as maculate.

Cladistics - Initial computer runs using the entire data set for the 12 taxa resulted in the discovery of $100+$ equally parsimonious trees (but only 18 different topologies when multifurcations are taken into account), all with a length of 23 steps and a consistency index of 0.565 . These cladograms are diverse in topology, and the strict consensus tree resulting from this initial analysis is merely a large polytomy, indicating only that the "insignis" group $(S$. saccata and $S$. radiosa) is most closely related to $S$. martiana, based on the presence of unicellular hairs on the osmophore and three teeth at the apex of the labellum in these species, and that $S$. tricornis Lindley may link with this clade owing to its bilayered osmophore tissue. In 14 trees, $S$. ecornuta Lemaire, $S$. pulla Reichb. f., $S$. annulata Mansf., and $S$. candida Barb. Rodr. comprise a paraphyletic or monophyletic group near the base of the tree (so placed because these species lack both mesochile horns and an articulated epichile), while in four trees these species form a monophyletic group near the apex (based on globose hypochile shape, a loss of mesochile horns, and loss of an articulated epichile). The reversal of an 

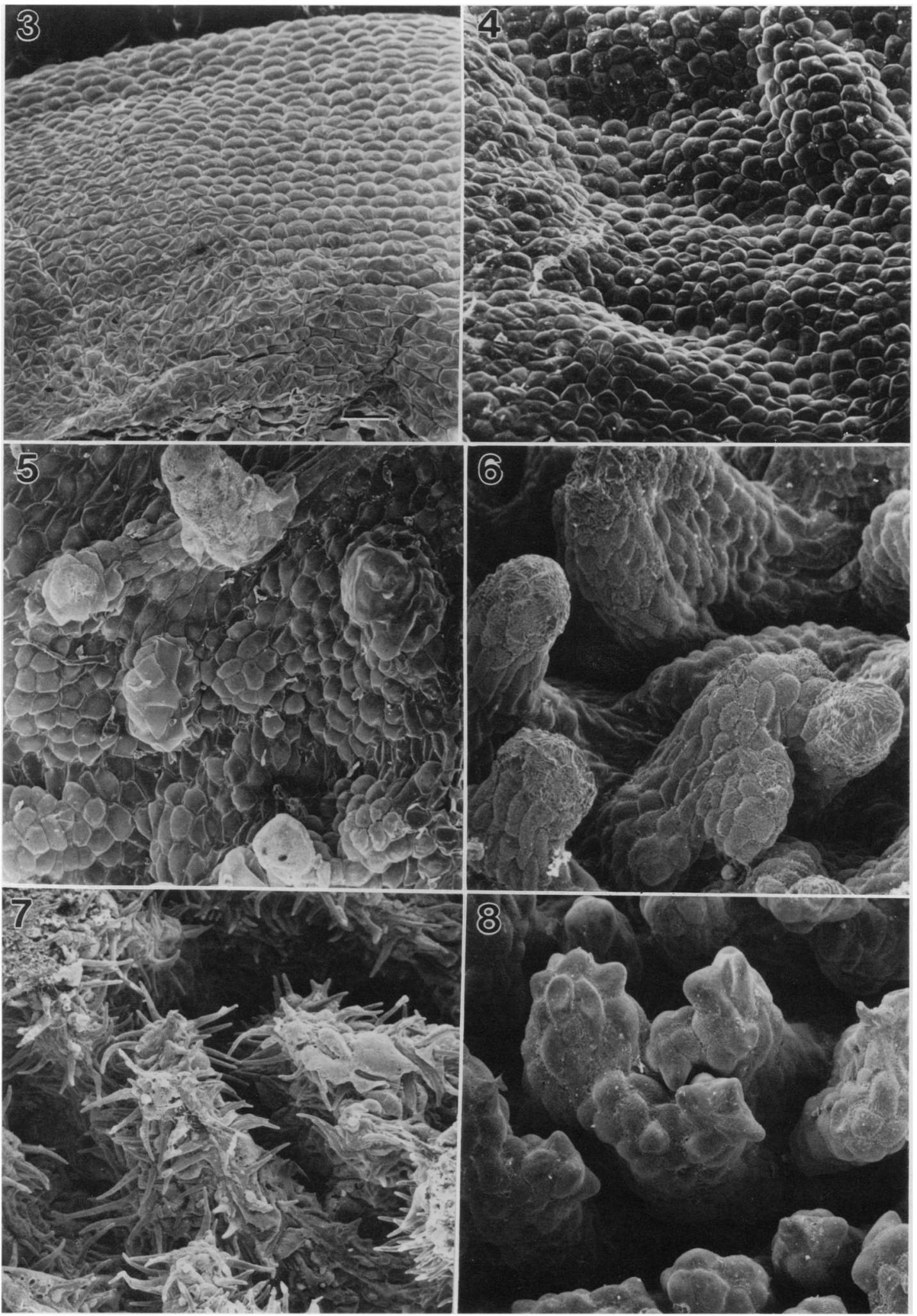
articulated epichile to a nonarticulated epichile (with a loss of horns on labellum) does not seem to be structurally or biologically meaningful. Thus, an additional cladistic analysis was conducted in which character 12 (articulated epichile) was weighted (by two) in order to inhibit homoplasy in this developmentally complex feature. The second analysis generated 84 equally parsimonious trees (but comprising only 14 different tree topologies) of 24 steps and with a consistency index of 0.583 . The strict consensus tree resulting from this analysis along with a representative cladogram showing distribution of character states is presented in Figs. 17, 18.

All trees discovered in the second cladistic analysis support the hypothesis that Stanhopea is monophyletic, based on the synapomorphies of the presence of a distinct hypochile (9) and flowers with reflexed petals (8). The latter character shows a reversal in $S$. tricornis. In all cladograms, $S$. pulla, $S$. ecornuta, $S$. annulata, and $S$. candida are positioned near the base; these species show many plesiomorphic characters. In addition, in most cladograms, $S$. ecornuta is cladistically basal, a position supported by its smooth osmophore surface (as well as its lack of other distinctive apomorphies; Figs. 17, 18); most species of Stanhopea included in the cladistic analysis (Fig. 17) likely form a monophyletic group on the basis of the synapomorphy of a rugose/papillate osmophore surface (1), although the osmophore surface has reverted to the smooth condition in $S$. vasquezii Dodson.

Stanhopea tigrina Bateman ex Lindley, $S$. martiana, S. tricornis, $S$. vasquezii, $S$. gibbosa Reichb. f., and members of the "insignis" complex ( $S$. saccata and $S$. radiosa) and the "oculata" group ( $S$. wardii, $S$. shuttleworthii, S. ruckeri, $S$. oculata, and $S$. anfracta) all form a monophyletic cluster, which can be recognized by the labellum with an articulated epichile (12) and a bicornuate mesochile (or hypochile; 11). These characters are morphologically (and likely developmentally) complex. Species relationships within this group are poorly resolved as can be seen in the consensus tree (Fig. 18). However, the two species of the "insignis" group are linked by the presence of cytoplasmic lipid inclusions of two types (4), and both species then link to $S$. martiana on the basis of unicellular hairs on the osmophore surface (2) and (in some trees, Fig. 17) by the additional feature of a labellum apex with three small apiculations (13). This unicellular-haired-osmophore clade then links with $S$. tricornis on the basis of a bilayered osmophore tissue (3), although it is noted that this character is homoplasious (see $S$. vasquezii, Fig. 17). In four cladograms, the clade characterized by bilayered osmophore tissue is positioned as the sister group of S. tigrina, the two being linked by the synapomorphy of a labellum apex with three small apiculations (13). However, in the remaining trees $S$. tigrina is isolated or linked with $S$. vasquezii, $S$. gibbosa, and members of the "oculata" group, because of its rectangular hypochile (10).

\section{DISCUSSION}

We have selected as the basic framework for our discussion of the systematics of the genus Stanhopea, the scheme (Fig. 1) published by Dodson and Frymire, and have compared our cladograms with this influential classification. Several species of Stanhopea that can be inserted at appropriate points in the original scheme have been described since that publication (Dressler, 1981; Dodson, personal communication). Dodson and Frymire's scheme includes two named complexes of species, two unnamed complexes, and several individuals with unusual characteristics that set them apart from any complex. As mentioned above, Sievekingia is considered by Dodson and Frymire (Fig. 1) as the ancestor of Stanhopea.

According to Dodson and Frymire, only those parts of the flower directly associated with pollination will be under strong selective pressure. Other parts of the flower can be expected to show more variation than those parts intimately associated with pollination. Evolutionary pressure on selected parts of orchid flowers has also been cited by Ackerman (1983). In Stanhopea, the labellum and its osmophore are closely associated with the attraction and orientation of the pollinator bringing that structure under strong selective pressure. The labellum has been the major feature used by Dodson and Frymire in constructing their evolutionary scheme for Stanhopea. Vegetative characteristics, since they are so uniform, have not been used.

Figs. 3-8. Scanning electron micrographs of osmophore surfaces of species of Stanhopea and Sievekingia. Bar = $100 \mu \mathrm{m}$. 3. Flat to bullate surface of Sievekingia suavis. 4. Flat to bullate surface of Stanhopea pulla. 5. Papillate surface of Stanhopea candida. 6. Papillate to rugate surface of Stanhopea tigrina. 7. Papillae with unicellular trichomes of Stanhopea saccata. 8. Papillae with short, unicellular trichomes of Stanhopea martiana. 

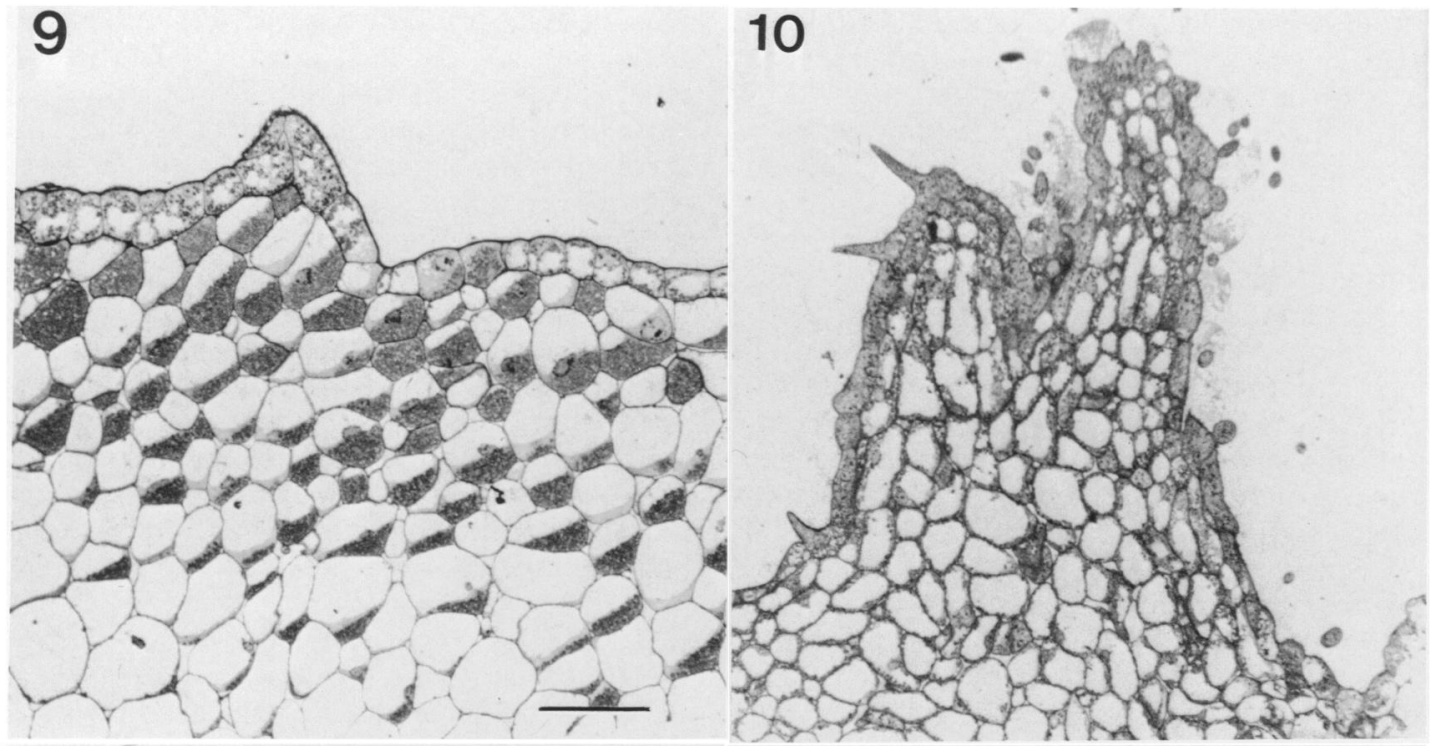

11

12

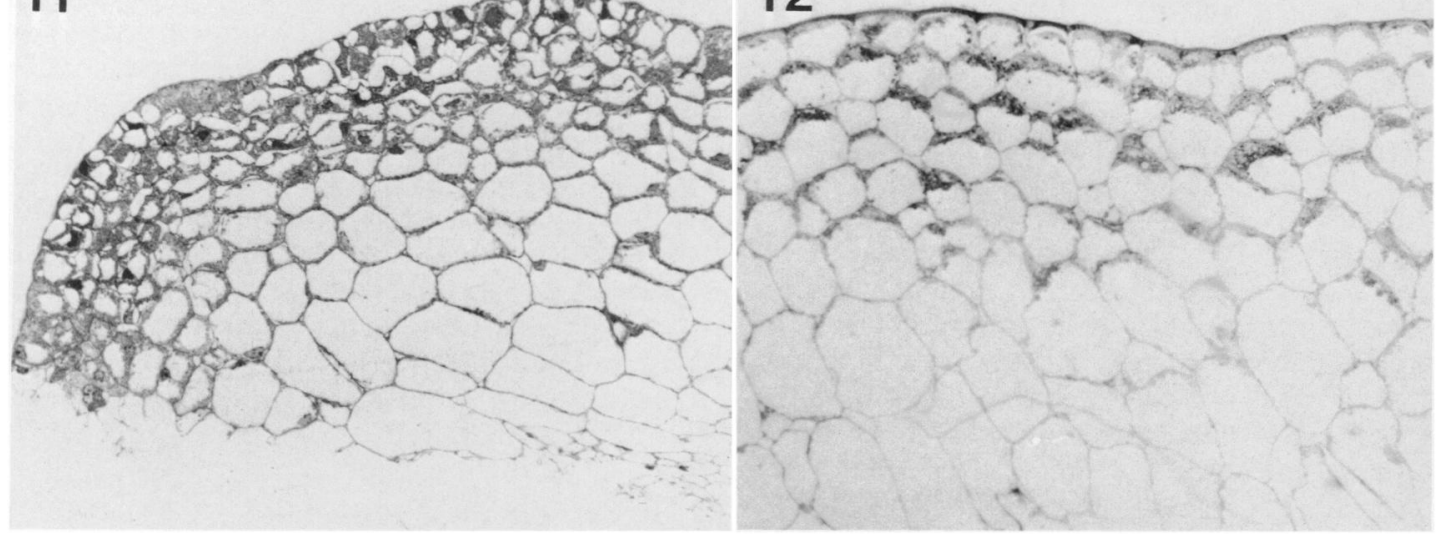

Figs. 9-12. Light micrographs of osmophores of Sievekingia and Stanhopea. Bar $=100 \mu \mathrm{m}$. 9. Bilayered osmophore of Stanhopea tigrina. 10. Bilayered osmophore of Stanhopea oculata. 11. Homogeneous osmophore of Sievekingia suavis. 12. Homogeneous osmophore of Stanhopea pulla.

Dodson and Frymire postulated a group of primitive stanhopeas derived from a species of Sievekingia, S. shepheardii Rolfe being the most primitive known species with respect to the slightly lobed, truncate lip. Sievekingia suavis Reichb. f., and $S$. peruviana Rolfe have more complex lips than $S$. shepheardii with erect side lobes forming a concave hypochile at the base. From these species, "the close relationships of the more primitive Stanhopeas are obvious," they attested. Figure 1 shows their scheme clearly with Stanhopea cirrhata Lindley and $S$. lewisae Ames \& Correll (neither species of which was available to us for study) linking the three more derived complexes: $S$. reichenbachiana Roezl ex Reichb. f., $S$. grandiflora (C. Lodd.) Lindley, and $S$. candida (the only species we had for study); the "insignis" complex including $S$. insignis Frost ex Hook., S. tigrina, $S$. saccata, $S$. radiosa, and $S$. martiana; and the "oculata" complex with $S$. oculata, $S$. wardii, $S$. vasquezii, S. gibbosa, S. shuttleworthii, S. ruckeri, and $S$. anfracta.

Stanhopea tricornis, an isolated species in the Dodson/Frymire scheme, shares some characteristics with members of the "insignis" complex except that its petals extend forward instead of being reflexed, and the horns arise from the hypochile instead of the mesochile. This is the only species of Stanhopea with anteriorly extended petals, and, because the petals in this species have a direct influence on the manner in which pollination is accomplished, Dodson and Frymire did not assign $S$. tricornis to one of their species clusters. 


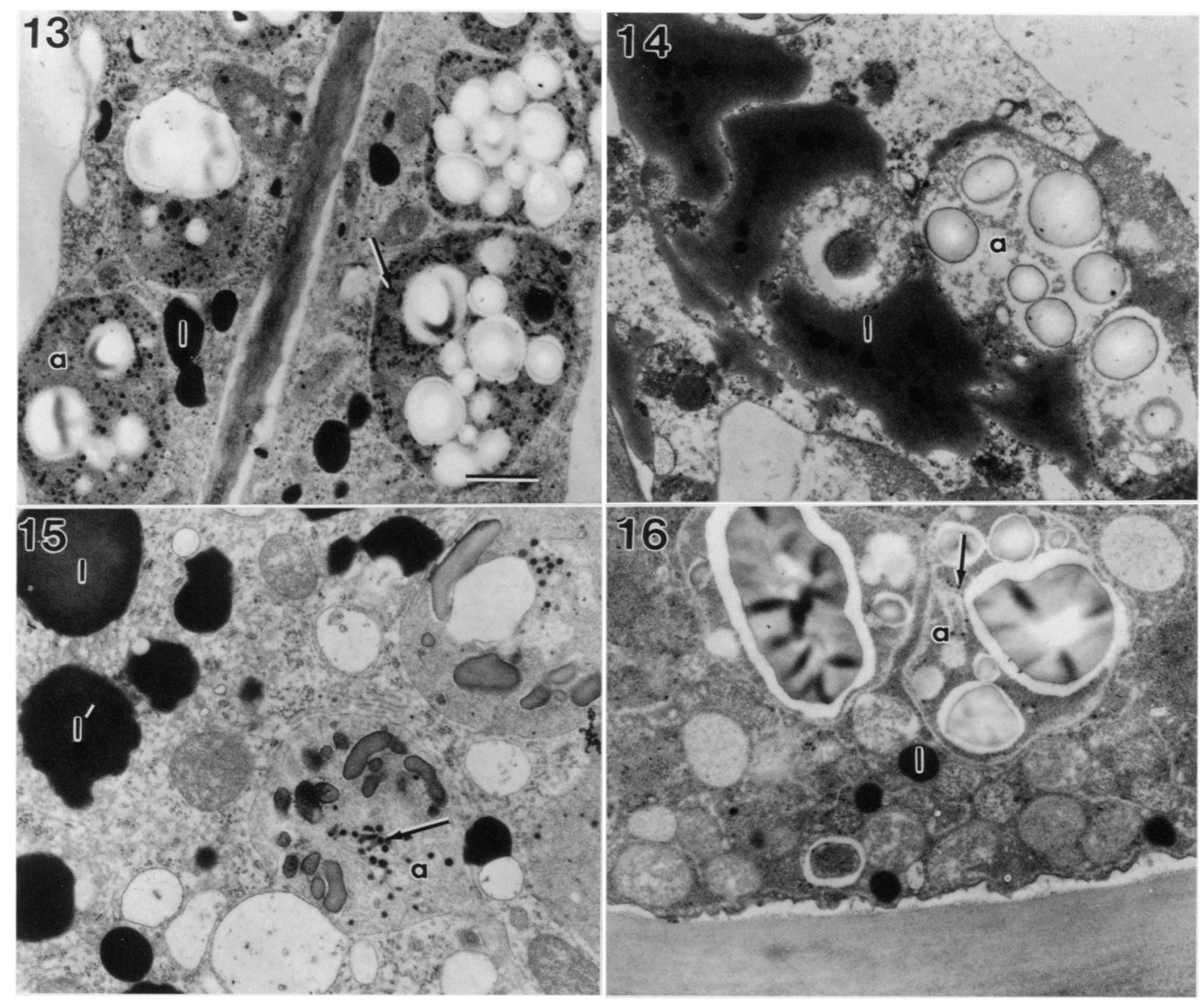

Figs. 13-16. Osmophore cells of Sievekingia suavis and species of Stanhopea. a = amyloplast, $1=$ lipid globule, arrow $=$ plastoglobulus. Bar $=0.1 \mu \mathrm{m}$. 13. Sievekingia suavis showing plastoglobuli and uniformly dense, spherical lipid inclusions. 14. Stanhopea pulla showing maculate, irregular lipid inclusions. Plastoglobuli were not observed. 15. Stanhopea saccata showing plastoglobuli and two different lipid inclusions $(1=$ dark periphery surrounding less dense center; $1^{\prime}=$ uniformly electron dense). 16. Stanhopea oculata showing plastoglobuli and uniformly dense, spherical lipid inclusions.

Osmophore characters - The relatively flat osmophore surface found in Sievekingia and in some stanhopeas offers less area for fragrance dispersal than the more convoluted surfaces characterized by papillae, rugae, and trichomes observed in flowers of the more derived stanhopeas. Anatomical differences between epidermal cells and subjacent cells may have involved general cell shape or the modification of the surface wall to form a trichome. The functional significance of trichomes is uncertain. Previously we postulated that plastoglobuli and cytoplasmic lipid inclusions were associated with fragrance production (Curry, 1987; Stern, Curry, and Pridgeon, 1987; Curry, Stern, and McDowell, 1988). The quantity and quality of fragrance produced is directly and strongly related to the effectiveness of pollination. All these characters were included in the cladistic investigation to assess their taxonomic utility.

We attempted to draw parallels between published data on individual components of fragrances (Williams and Whitten, 1983) and our character set, but without success, and agree with the comments by Williams and Whitten that more detailed information is needed before this line of inquiry will prove fruitful. We suggest that the morphological distinctions we have noted in lipid inclusions represent rough aggregations of fragrance or fragrance precursors. No specific correlations can be made between lipid inclusions and individual fragrances or groups of fragrances. As with lipid inclusions, we view the presence or absence of plastoglobuli as a crude measure of some aspect of fragrance production. The main difficulty in assessing this character is in proving the ab- 


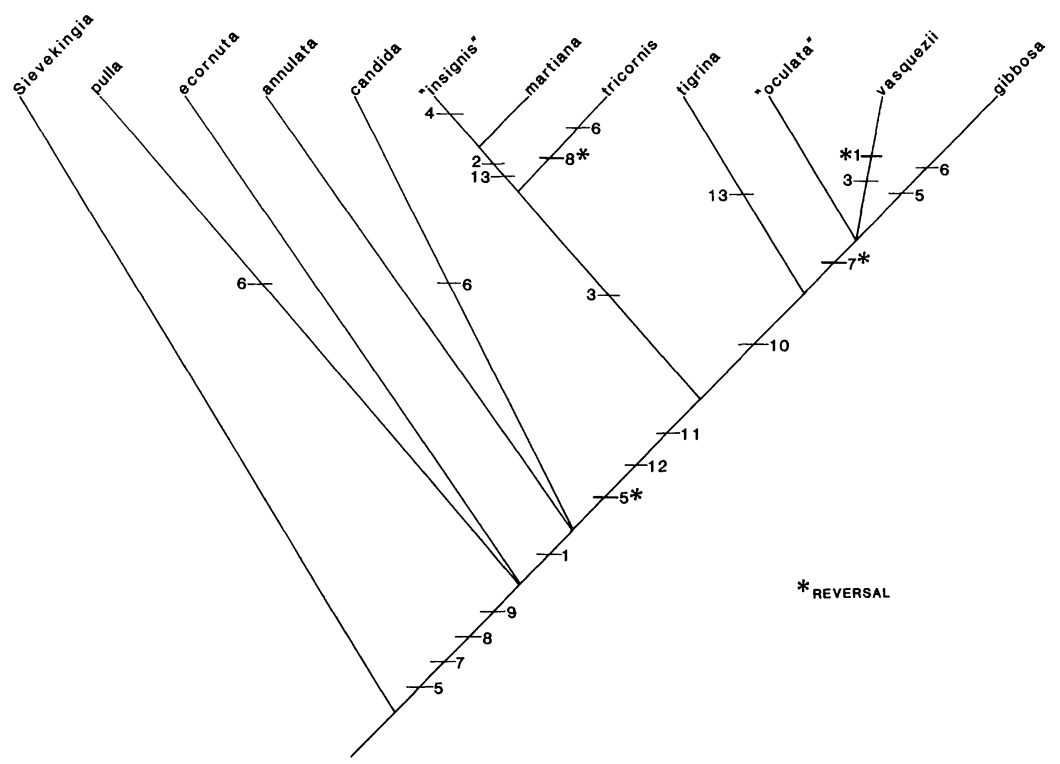

Fig. 17. Representative tree resulting from analysis in which character 12 was weighted (see discussion in text). Taxa indicated by specific epithet (or name of species complex); characters as in Tables 1,2 , and text.

sence of plastoglobuli. Plastoglobuli may be produced infrequently in the amyloplasts of cells where we report no production. Thus, our data may represent relative production rather than absolute production.

Other floral characters - Visual cues are apparently unimportant in the pollination system of Stanhopea (Dodson and Frymire), so the massing of flowers for visual display may likewise be considered unimportant. However, the possession of inflorescences with numerous vs. few flowers may enhance the long-range attraction of pollinators through increased fragrance production. Species of Stanhopea in our greenhouse generally produced flowers in pairs or in clusters of five or more. We divided the species into those that produce three or fewer flowers per inflorescence and those that produce four or more per inflorescence. The ancestral state in Sievekingia seems to be the production of a large number of flowers leading to a reduction in floral number in ancestral stanhopeas. The more elaborate pouch in

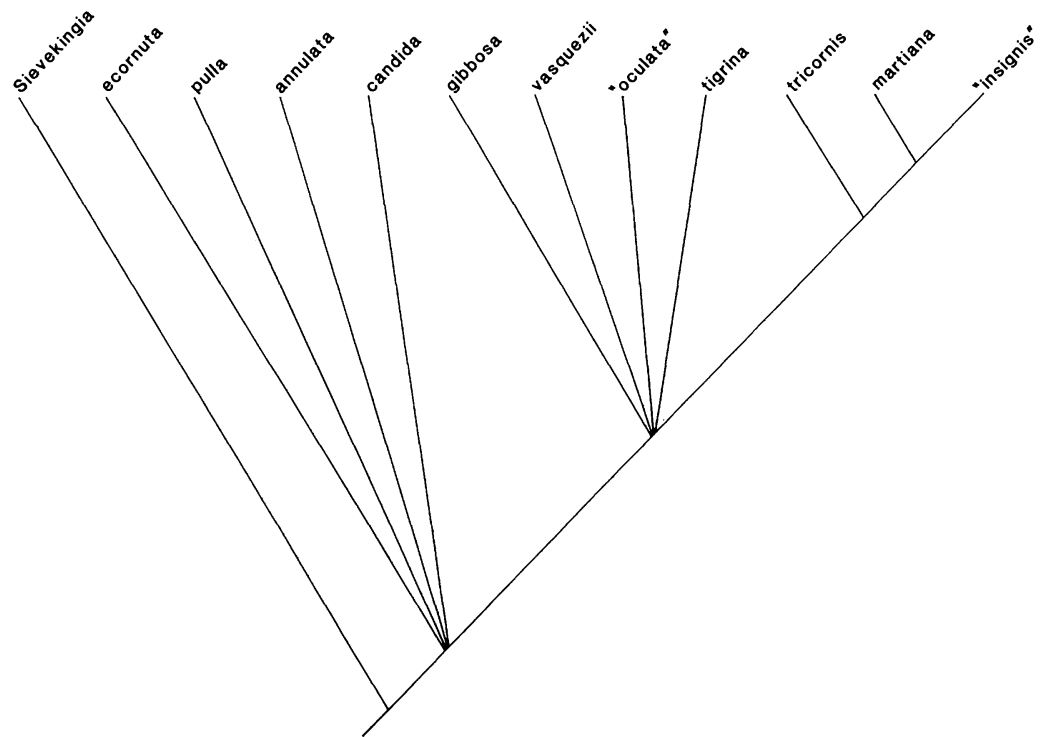

Fig. 18. Strict consensus tree of 84 equally parsimonious 24-step cladograms discovered in above-mentioned analysis. 
"primitive" stanhopeas probably increases their capacity for fragrance production over that in Sievekingia. After these events, selective pressure seems to have favored the development of more elaborate osmophores and, in some species, decreased floral number.

One of the most obvious advances from the ancestral stanhopeas is the development of a horned mesochile and an articulated epichile. This relates to the "slide-fall" mechanism by which Stanhopea is pollinated (Pohl, 1927). A euglossine bee enters the flower from either side landing on the labellum. In the course of collecting fragrance (there is no food reward), the bee apparently becomes disoriented by the fragrance and falls out of the flower between the epichile of the labellum and the tip of the column where the pollinia are located. The pollinia are attached to the bee by a sticky pad, the viscidium, as the bee exits the flower. The stigma, located just behind the anther, becomes receptive to the pollen after the pollinia are removed so that a second visit by a bee carrying pollinia may result in pollination as the second bee falls through the flower leaving its pollinia on the sticky stigma.

The development of mesochile horns established a mechanism to ensure that bees would fall straight from the fragrance-producing region of the hypochile, and past the pollinia and stigma, not out to one side, thus missing the pollination target. The articulated epichile, which is associated with mesochile horns (hypochile horns in $S$. tricornis), acts as a spring between the epichile and column tip. That distance is critical to effective pollination. A spring mechanism allows a great degree of tolerable variation in both the size of the individual pollinator and the distance between the epichile and column tip while still maintaining a high success rate in effective pollination.

The reflexed petals, of course, are an integrated part of "slide-fall" pollination. Stanhopea tricornis and Sievekingia species, with their petals directed forward, preclude entry into the flower from the side. Instead, the pollinator must enter from the front and back out of the flower the way it came in. Stanhopea tricornis has horns arising from the hypochile to guide a falling bee. The distance between the column tip and the epichile is still critical to pollination, but the bee need not fall from the flower.

The shape of the hypochile (rectangular or globose) and the number of apiculations or lobes on the epichile are arcane characters as far as present data are concerned. Interestingly, there is a strong correlation in Stanhopea between hypochile shape and whether the cells of the osmophore are bilayered or homogeneous. The globose hypochile in conjunction with mesochile horns is always associated with a bilayered osmophore, and a rectangular hypochile is associated with a homogeneous osmophore in every specimen examined except $S$. vasquezii. Curiously, $S$. vasquezii is the only member of the "oculata" complex of species that has a smooth osmophore surface. The significance of these observations remains obscure.

Correlation between the various characters discussed above and specific pollinators was attempted without success. Too little is known about the pollination of specific species of Stanhopea (Williams, 1983) to derive meaningful correlations. Dressler (1981) has described general associations in Stanhopea between pollinator size and flower size.

Cladistics - The cladogram presented in Fig. 17 (based on floral morphology as well as ultrastructural and micromorphological features of the osmophore) is representative of most of the discovered trees, and supports the traditional (i.e., evolutionary taxonomic) classification proposed by Dodson and Frymire. In their evolutionary tree, Stanhopea ecornuta and $S$. pulla are positioned at the base of the genus, and the species with horns on the labellum form a monophyletic group (except for $S$. tricornis). Within the group possessing mesochile horns, a close connection is seen between $S$. insignis, $S$. martiana, and $S$. tigrina, on one hand, and $S$. wardii and $S$. oculata, on the other. Our cladograms, in large part, support these evolutionary hypotheses. Dodson and Frymire's "insignis" complex may be monophyletic (although placement of $S$. tigrina is problematic), and the members of their "oculata" complex form either a monophyletic group (Fig. 17, supported by ten trees) or a paraphyletic group (supported by four trees, not shown) in our analysis. The strict consensus tree (Fig. 18) indicates the branching points supported by all discovered cladograms. It is evident that all trees support the monophyly of Stanhopea, as well as the distinctly basal position of $S$. ecornuta and $S$. pulla relative to the monophyletic group of species with articulated epichiles and horns. This broad agreement is perhaps to be expected, since both our cladograms and Dodson and Frymire's evolutionary tree employed many of the same floral characters, and both assumed that Sievekingia is the ancestor of Stanhopea. However, it is noteworthy that several ultrastructural/ micromorphological characters, e.g., osmophore surface texture (smooth vs. rugose/papil- 
lose), osmophore indumentum (presence vs. absence of unicellular trichomes), osmophore tissue differentiation (homogeneous vs. bilayered), and cytoplasmic lipid inclusions, are useful in discerning phylogenetic relationships and support groupings established on floral morphological features (Fig. 17).

A significant difference between the cladograms presented here (Figs. 17, 18) and Dodson and Frymire's tree is seen in the position of Stanhopea tricornis. Dodson and Frymire placed this species in an isolated position and derived it from ancestors similar to Sievekingia trollii Mansf. Thus, they hypothesized that its articulated epichile and labellum horns originated independently from those of the other species of Stanhopea. This evolutionary hypothesis would make the genus Stanhopea a polyphyletic evolutionary grade. One could even argue that the positioning of the labellum horns on the hypochile (instead of the mesochile) in S. tricornis may indicate that the horns of this species are not homologous with those of other species of Stanhopea, although their structure is very similar. However, in their discussion they suggest an alternative hypothesis, that " $S$. tricornis may have been derived as a result of hybridization between Sievekingia trollii or a similar form and some Stanhopea sympatric in distribution" (Dodson and Frymire). They suggest Stanhopea bucephalus Lindley as a possible parent and state that "if chance pollination of Stanhopea bucephalus by the Sievekingia should occur the resulting intermediate hybrid might well be visited by a pollinator not utilized by either parental species and thereby be stabilized as a species." If this hypothesis is accepted, then Dodson and Frymire's evolutionary tree can be viewed as supporting the monophyly of Stanhopea.

Our cladograms support their second hypothesis, i.e., the view that $S$. tricornis is of hybrid ancestry. Stanhopea tricornis has been consistently placed among those species of Stanhopea with an articulated epichile and a horned labellum. This placement is strengthened by the fact that $S$. tricornis shows a bilayered osmophore. However, the species exhibits a reversal from reflexed to erect petals, a characteristic of Sievekingia, and shows other similarities with Sievekingia not included in our analysis but discussed by Dodson and Frymire.

The consistent linking of $S$. tricornis with the species of Stanhopea possessing articulated epichiles is not surprising; one would expect it to join with the parent possessing the most apomorphic characters. Hypothesizing a hybrid ancestry for $S$. tricornis (i.e., between a species of the articulated epichile clade and Sievekingia) would provide an explanation of the reversal to erect petals seen in this species.

Positioning of the labellum horns on the hypochile in S. tricornis may relate to the interplay among the divergent developmental pathways of the labellum in the parental species. Additional biosystematic investigations are clearly needed to clarify this situation, but at present we prefer the hypothesis that $S$. tricornis is of hybrid ancestry. Such a hypothesis is much more parsimonious than one that derives this species as a separate lineage (evolving Stanhopea-like features in parallel).

\section{LITERATURE CITED}

ACKerman, J. D. 1983. Specificity and mutual dependency of the orchid-euglossine bee interaction. Biological Journal of the Linnean Society 20: 301-314.

AlmeidA, M. T. AND F. A. BisBy. 1984. A simple method for establishing taxonomic characters from measurement data. Taxon 33: 405-409.

CURRY, K. J. 1987. Initiation of terpenoid synthesis in osmophores of Stanhopea anfracta (Orchidaceae). American Journal of Botany 74: 1332-1338.

-, W. L. STERN, AND L. M. McDowell. 1988. Osmophore development in Stanhopea anfracta and $S$. pulla (Orchidaceae). Lindleyana 3: 212-220.

Dodson, C. H. 1963. The Mexican stanhopeas. American Orchid Society Bulletin 32: 115-129.

1975a. Clarification of some nomenclature in the genus Stanhopea (Orchidaceae). Selbyana 1: 46-55.

1975b. Orchids of Ecuador: Stanhopea. Selbyana 1: 114-129.

- AND G. P. FRYMIRE. 1961. Preliminary studies in the genus Stanhopea (Orchidaceae). Annals of the Missouri Botanical Garden 48: 137-173.

DRESSLER, R. L. 1981. The orchids: natural history and classification. Harvard University Press, Cambridge, MA.

1982. Biology of the orchid bees (Euglossini). Annual Review of Ecology and Systematics 13: 373394.

FAHN, A. 1979. Secretory tissues in plants. Academic Press, New York.

Hayat, M. A. 1981. Principles and techniques of electron microscopy: biological applications, $2 \mathrm{~d}$ ed., vol. 1. University Park Press, Baltimore.

HeNDY, M. D., AND D. PENNY. 1982. Branch and bound algorithms to determine minimal evolutionary trees. Mathematical Biosciences 59: 277-290.

MADDISON, W. R., M. J. DoNOGHUE, AND D. R. MADDISON. 1984. Outgroup analysis and parsimony. Systematic Zoology 33: 83-103.

MeIKLE, R. D. 1980. Draft index of author abbreviations compiled at the Herbarium, Royal Botanic Gardens, Kew. Her Majesty's Stationery Office, London.

PoHL, F. 1927. Die anatomischen Grundlagen für die Gleitfallenfunktion der Blüten von Stanhopea tigrina und St. oculata. Jahrbücher für wissenschaftliche Botanik 66: 556-577.

SchNePF, E. 1969. Gland cells. In A. W. Robards [ed.], Dynamic aspects of plant ultrastructure, 331-357. McGraw-Hill, New York.

SPURR, A. R. 1969. A low-viscosity epoxy resin embed- 
ding medium for electron microscopy. Journal of $\mathrm{Ul}$ trastructure Research 26: 31-43.

Stern, W. L., K. J. Curry, AND A. M. Pridgeon. 1987. Osmophores of Stanhopea (Orchidaceae). American Journal of Botany 74: 1323-1331.

STEVENS, P. F. 1980 . Evolutionary polarity of character states. Annual Review of Ecology and Systematics 11: 333-358.

- 1981. On ends and means, or how polarity criteria can be assessed. Systematic Botany 6: 186-188.

SwOFFORD, D. L. 1985. PAUP: phylogenetic analysis using parsimony, version 2.4. Illinois Natural History Survey, Urbana.

VoGel, S. 1963. Duftdrüsen im Dienste der Bestäubung über Bau und Funktion der Osmophoren. Akademie der Wissenschaften und der Literatur. Abhandlungen der mathematisch-naturwissenschaftlichen Klasse 10: 598-763.

WheELER, Q. D. 1981. The ins and outs of character analysis: a response to Crisci and Stuessy. Systematic Botany 6: 297-306.

Wiley, E. O. 1981. Phylogenetics. John Wiley and Sons, New York.

WiLliams, N. H. 1983. Floral fragrances as cues in animal behavior. In C. E. Jones and R. J. Little [eds.], Handbook of experimental biology, 50-72. Van Nostrand Reinhold, New York. , AND W. M. Whitten. 1983. Orchid floral fragrances and male euglossine bees: methods and advances in the last sesquidecade. Biological Bulletin of the Marine Biological Laboratory Woods Hole 164: 355-395. 